\title{
EVALUATION OF THE BODILY-KINESTHETIC INTELLIGENCE MODEL IN PHYSICAL EDUCATION TEACHING IN INDONESIA PRIMARY SCHOOL
}

\author{
Suhadi Suhadi*, Soegiyanto Soegiyanto, Hari Amirruloh Rahman, Sulaiman Sulaiman \\ Yogyakarta State University, Indonesia \\ *e-mail: suhadi_fik@uny.ac.id
}

\begin{abstract}
Bodily-kinesthetic intelligence model refers to a person's potential to body fact system via hand and physique movement, control, and expression. This model is still rarely known in Indonesian primary school. The aim of this research was to determine the current bodily-kinesthetic intelligence model in physical education teaching for primary schoolers. Descriptive research was conducted with a qualitative and quantitative approach. The sample of this study was physical education teachers and primary school students. Literature review of the documents, questionnaire, observation, video recordings, photography and diary were used to explore the level of the student mind and fitness body. The result showed that the current Bodily-kinesthetic intelligence model in Physical Education Teaching did not allow the appearance of increasing the maximum of their physical and mental abilities. In conclusion, this study gives the assessment model of student human kinetic in order to fix the current issue of competence evaluation. Physical education teachers need to improve their teaching methods to allow students to reach physical and mental performance.
\end{abstract}

\section{Keywords: evaluation, bodily-kinesthetic, intelligence, physical, education}

\section{EVALUASI MODEL KECERDASAN KINESTETIK TUBUH DALAM PEMBELAJARAN PENDIDIKAN JASMANI DI SEKOLAH DASAR INDONESIA}

\begin{abstract}
Model kecerdasan kinestetik tubuh mengacu pada potensi seseorang untuk sistem fakta tubuh melalui gerakan tangan dan fisik, kontrol, serta ekspresi. Model tersebut masih belum diketahui di sekolah dasar Indonesia. Penelitian ini bertujuan untuk memeriksa model kecerdasan Bodily-kinestetik dalam pembelajaran pendidikan jasmani untuk siswa sekolah dasar. Penelitian ini adalah studi deskriptif dengan pendekatan kualitatif dan kuantitatif. Sampel penelitian ini adalah guru pendidikan jasmani dan siswa sekolah dasar. Studi pustaka terhadap dokumen, angket, observasi, rekaman video, fotografi dan buku harian digunakan untuk mengeksplorasi level pikiran dan kebugaran tubuh siswa. Hasil penelitian menunjukkan bahwa model kecerdasan kinestetik-jasmani dalam pembelajaran pendidikan jasmani saat ini tidak memfasilitasi peningkatan kemampuan fisik dan mental siswa secara maksimal. Penelitian ini memberikan model penilaian pada kinetik siswa untuk memperbaiki masalah evaluasi kompetensi saat ini. Guru pendidikan jasmani perlu meningkatkan metode pembelajaran agar memungkinkan siswa untuk mencapai kinerja fisik dan mental.
\end{abstract}

Kata Kunci: evaluasi, kinestetik-tubuh, kecerdasan, jasmani, pendidikan

\section{INTRODUCTION}

Physical Education and Sports is one of the subjects taught in primary schools. This subject depends on sports and creative bodily activities for support. It is essential in such areas as health, cognitive, intellectual, social, physiological, and psychological, the standards accessible software that has been affecting younger athletes and affordable (Siswantoyo, Shaari, \& Hooi, 2019). The human body movement function was bound with wisdom. The motoric skills subjects were depending on the individual manner, and the inclusive physical games were very helpful for them (Mitchell \& Kernodle, 2004). Cleverness is an innate plausible present in every individual, exploring and expressing it can be profitable through the mastering activities. Some learners choose to learn through movement as well. They are indeed termed as kinesthetic beginners or possess kinesthetic intelligence. The creativity of instructors is by some means confronted with the best assignment from the remaining concept of 
teaching. However, identical defies are seemed at in the improvement of information transfer strategies (see Suherman, Dapan, Guntur, \& Muktiani, 2019).

The repertoire of methods and techniques is planned by the course tutorials. Cooperation is possible among teachers whose areas of expertise are completely different from each other in relation to the different types of classroom activities. For example, teachers need to communicate and get advice from the physical education teacher when planning an activity related to physical intelligence and skills (Schewe, 2002). In each area, there are strong and weak sides for the learner, which is why we need an evaluation of kinesthetic intelligence. The school environment is one of the factors that accelerates the obtaining of intelligence, therefore we determine to learn over a long period without benefiting or never managing to learn. By consulting the relevant literature, it is possible to find several research studies that focus on determining the types of intelligence and the impact of a subject discussed according to the theory of multiple intelligence on student success, the permanence of knowledge and attitude.

Education status today is influenced by the competence behavior was laid to the implications of MI theory - the powerful notion has been reached by many explores, the researchers' results have demonstrated distinct human capabilities linking student's capacities which happened in past decade. The motivation and enthusiasm are psychological characteristics of students and a less stressful day in all areas. All students will benefit from this instant messaging education and may reach higher standards. We are able to understand the role of multiple intelligence through a variety of tools. "With increased knowledge and power, teaching will be A pleasure. Student success is a teaching function to reduce stress. Students will be highly motivated and their individual skills will be fully achieved. Quality education depends on in-depth knowledge, deepening of the means of delivering content as well as knowledge required by the teacher. In the case of motor skills teaching, quality teaching involves knowing how students learn coordination, skills of learning to walk. There are many case of knowledge. This statement has 3 items which are necessary. Biopsychological was a modified terminology of knowledge, potential for processing news. The foregoing were based on cognitive teaching; intelligence is justified by the fact that the child is able to find a solution to his problems. thinking skills and knowledge help the learner to adapt effectively to his environment using (FergusonPatrick, Reynolds, \& Macqueen, 2018).

Questioning has been afforded in measurement of behavior social human are consciously elevated in the definition of Gardner. It also extends the performance of talent to include making beneficial products, not simply hassle solving. Next, he knew brain's capacity (Morgan, 1996). In addition, there were many case of knowledge according to the subjects surveyed. In twentieth century, many psychometricians certainly saw clever in one portion, like he has been approved. The terminology g which means general was shot down first by by Charles Spearman as a behavior of wisdom. One is only qualified gift when one obtains several $\mathrm{g}$; . Since 1930, some researchers (notably Louis L. Turnstone) already presented a multidimensional orientation of knowledge. the obligation to use a few concepts was for example the case of mathematics.

From the 1950s, many psychometricians had hierarchical types of education, which can be taken as a set of 1 problem and 2 types of components. With the exception of a few reluctants, many psychologists often preferred the hierarchical model. We are at the give up of this millennium impatiently ready and excitement, the subsequent millennium is going to offer. Gradually adjustments were made in a variety of fields. The world is very competitive. The competition also opens up amazing possibilities for all and sundry who is prepared to take advantage of the identical thing. criticism held at some point of the educating course will allow change. Throughout the world, the emphasis on training has grown not only from academic excellence but also from global excellence. In this context, the concept of Multiple Intelligence is very important. To meet the challenges of change, college students have to be developed in accordance to distinctive parameters. Much lookup has been executed to recognize human excellence (Barrington, 2004).

The intelligence at the command of the human machine has been studied from a number operspectives. One researcher is Dr. Howard Gardner, who has accomplished massive lookup 
on human excellence. He defines talent as "the ability to resolve problems that block in actual existence and the ability to produce new problems to be solved. He stated that the human thinking have to also have the potential to create something or to provide offerings that are valued in its culture.

It focuses on eight kinds of Genius as follows: (i) Linguistic intelligence: it is the capacity of students to categorical ideas and concepts with words.Play a very imperative role in the coming years and college students must be in a role to categorical them really and concisely so they can alternate their knowhow turns into a usable product Students with high degree of linguistic Genius behave very nicely as writers, speakers and journalists. (ii) Logical-mathematical intelligence: it is the capability to focus on my mathematical problems, assumptions and assume logically. Engineers, laptop programmers and researchers all have a high level of intelligence. (iii) Spatial intelligence: this is a very vital ability that will enable one to assume in three-dimensional perspectives. This requires a excessive stage of visible picture and creativity itself. Students with spatial intelligence have the capability to turn out to be architects, painters or pilots, who need these capabilities in the every day software of their work. (iv) Kinesthetic-body intelligence: this knowledge is the capacity to manipulate various objects. This additionally requires better physical skills. We will respect the extent to which athletes and sportsmen manipulate their bodies. If this intelligence is developed properly; college students will be able to shine as sportsmen, dancers or surgeons.

(v) Musical intelligence: the Genius has two parts, specifically the left hemisphere and the right hemisphere. The left hemisphere is logical, mathematical and linguistic. On the different hand, the proper hemisphere is one the place talents for track and creativity develop. Students with a high stage of musical talent are motivated through the proper brain. These college students demonstrate their capability to apprehend and contribute to music. They can admire parameters such as tone, melody, rhythm or tone. Students who excel in this discipline emerge as amazing composers, music directors, track critics, or instrument makers. If this intelligence develops in students, their right
Genius is activated and they start to suppose creatively. (vi) Interpersonal knowledge: this is basic to improve relationships and human beings administration skills. rsonal intelligence: This is the potential to introspect and recognize oneself in a new dimension. It also includes the potential to diagram beforehand and stay your life. Students with very excessive stages of intra-personal intelligence can recognize their strengths and weaknesses. Students with this ability will grow to be theologians, psychologists, philosophers or unique thinkers. (viii) Intelligence: it is the capacity to recognize nature and use the gifts of nature for one's own development. Students with excessive level of naturalistic brain do well as agriculturists, farmers, landscapers, etc. It is feasible in an instructional organization to enhance the above eight kinds of intelligences for all children who really want to improve talent.

Human movement knowledge was described like man or woman's capability to operate his physic in unraveling difficulties, specific ideas and control parameters. Referring to the previous theory, a simple attribute of this kind of genius is the ability to hire the physical in a do-it-yourself form that requires talent to harvest one's goals. A $2 d$ characteristic of the human movement which is controlled by sympathies nervous is the motoric improving in handling parameters (Michelaki \& Bournelli, 2016). Physical education and activity are imperative rights for all. Every human being has the acceptable to get entry to bodily training and sports, which are necessary to the enchancment of personality. Sport has the potential to achieve a large proportion of younger humans and young people (Seitz, 1992). Siswantoyo (2014) tested that concluded that the modified plyometric training model must be used as an preference teaching to beautify the health of athletes. the curriculum for learning physical activities is addressed by schoolchildren of age in accordance with the law of primary education a range of courses made up the program, namely: table tennis, running, long and high jumps, etc (Bailey, 2005).

The right to develop bodily as nicely as mental and moral competencies thru physical education and sports activities need to be guaranteed each in the schooling machine and in other components of social existence the idea 
that video games might show to be an antidote to anti-social behaviour amongst working-class (Ericsson, 2014). Well-being for a total bloom. It also influences the development of bodily traits and the intellectual, ethical and social formation of the toddler (Lynch, 2016). In addition, it has the workable to impact the development of young humans in every of these areas: physical, social, emotional and cognitive. Learning physical education and sport in foremost faculties has not touched the improvement of the multiple intelligences of children. The aim of this research was to determine the current Bodilykinesthetic intelligence model in physical education teaching in Indonesia Primary School.

\section{METHODS}

This study was a descriptive research with mixed-method quantitative and qualitative approaches. The sample of this study was physical education teachers and primary school student that choose by random sampling. Data were collected using a literature review of the documents, questionnaire, observation, video recordings, photography and diary. $\quad \mathrm{D}$ a $\mathrm{t}$ a related to childhood needs, curriculum suitability, and student characteristics were obtained through interviews or direct communication techniques with elementary school teachers, observation, and documentation.

The survey was considered as a guided and independent manner, there were guidelines used to interview respondents, as well as observation and documentation assisted with written guidelines. The interview guide is in the form of question items that are arranged based on the problems investigated, especially student need in the physical education learning process. These questions include: (1) Face-toface learning hours and frequency which are given per week; (2) Props used for learning; (3) Existing and frequently infrastructure used; (4) Physical education learning materials used; (5) Teacher knowledge about basic movements; (6) Allocation of time for implementing learning using physical activities; (7) Obstacles and difficulties encountered; and (8) Conformity between content with the objectives of each activity. Data were analysed using SPSS AMOS 21.

\section{FINDINGS AND DISCUSSION Findings}

Physical education and sport in primary schools emphasis body kinesthetic intelligence development. The use of organized and systematic physical activity/movement as a vehicle to achieve the goal of teaching physical education and sport will trigger a child's body kinesthetic intelligence. The Table 1 showed seven items in the multiple intelligences which support the learning of physical education and sport in accordance with the current curriculum.

On the other hand, physical education and game can additionally set off the improvement of emotional genius related to psychological

Table 1. Main Items in the Current Curriculum of Physical Education and Sport

\begin{tabular}{|c|c|c|c|}
\hline & $\begin{array}{c}\text { Multiple } \\
\text { Intelligences }\end{array}$ & Description Intelligence & Forms of Activities/Roles Sports \\
\hline 1. & Interpersonal & $\begin{array}{l}\text { Verbal and non-verbal communication, } \\
\text { relating to others }\end{array}$ & Captain, coach \\
\hline 2. & Bodily-body & $\begin{array}{l}\text { Fine and gross motor skills, } \\
\text { coordinating the body }\end{array}$ & Friend instructions/demonstration \\
\hline 3. & Visual-spatial & $\begin{array}{l}\text { Interpreting and describing spatial } \\
\text { graphic }\end{array}$ & $\begin{array}{l}\text { Training, describing the game } \\
\text { strategy }\end{array}$ \\
\hline 4. & Music & $\begin{array}{l}\text { Valuing and knowing the tempo, } \\
\text { acoustic and dance talent }\end{array}$ & $\begin{array}{l}\text { Selecting sound's training and } \\
\text { competition }\end{array}$ \\
\hline 5. & $\begin{array}{l}\text { Analytical- } \\
\text { mathematical }\end{array}$ & $\begin{array}{l}\text { Assessing the pattern of the game, a } \\
\text { rationale, victory/defeat }\end{array}$ & $\begin{array}{l}\text { Calculating the score of the game, } \\
\text { analyzing the game }\end{array}$ \\
\hline 6. & $\begin{array}{l}\text { Speaking } \\
\text { language }\end{array}$ & Manipulating the writing and reading & $\begin{array}{l}\text { Creating games for the publication } \\
\text { of the school newspaper }\end{array}$ \\
\hline 7. & Intrapersonal & The control and self-recognition & Owner group \\
\hline
\end{tabular}


aspects. The enjoyable physical undertaking/ movement in a team would foster cooperation, responsibility, and so on. It will have an impact on the emotional brain of elementary school children. As such, the mind is related to how people linked to the environment and characters. People with natural talents are very sensitive to climate change and have the ability to differentiate, classify, and exploit ecological problems. The genius of numerical/analytical Mathematical/logical linked with the expected derivative of, and, on a various relationship. Those who are consistent in mathematical thinking/mathematical logic in problem solving, finishing the results, and identifying family members as to cause and effect. These people are very afraid to inspect, track, analyze, create, and use numbers with collaborators. The genius of logic-calculator allows humans to use and respect personal relationships. Scientists, mathematicians, and philosophers remember this spirit.

So What? University students living the reality of baseball or who consciously analyze problematic situations that are not public and related schools before looking for a systematic solution? Genius interactive collaboration tips are used when people have direct interaction with others. The people that strong in this brain focus on caring for others and reading in collaboration with others. These people are characterized by management skills, friendship skills, and the ability to understand aspects of a single perspective from them. The personal interactions of people whose interactively oriented learning style can focus on and maintain local influence. They can use that brain to be positive. They know their personal feelings, strengths, opinions, values, and beliefs. They are happy to keep and respond to wishes and spend time in public for taking responsibility.

The result of evaluation of physical education leaning model in the current curriculum based on this research is presented in Table 2. Table 2 showed that there are many children who are still at a low level of bodilybody kinesthetic intelligence. Figure 1 explained this finding more clearly.

\section{Discussion}

To abandon the final result of the research shows, the current model of body-kinesthetic talent in power Physical Education Teaching is not allowed to present all your care and use a lot of kinesthetic intelligence. The man has two faculties, which are both in the physical sense, it is

Table 2. Evaluation of the Physical Education Leaning Model in the Current Curriculum

\begin{tabular}{crrrcrcc}
\hline \multirow{2}{*}{ No. } & \multirow{2}{*}{ Intelligence } & \multicolumn{6}{c}{ Category } \\
\cline { 2 - 8 } & & \multicolumn{2}{c}{ Low } & \multicolumn{2}{c}{ Moderate } & \multicolumn{2}{c}{ High } \\
\hline 1 & Bodily-body & 37 & $46.8 \%$ & 42 & $53.2 \%$ & 0 & $0 \%$ \\
2 & Emotional & 2 & $2.5 \%$ & 21 & $26.6 \%$ & 56 & $70.9 \%$ \\
\hline
\end{tabular}

Intellectual Category

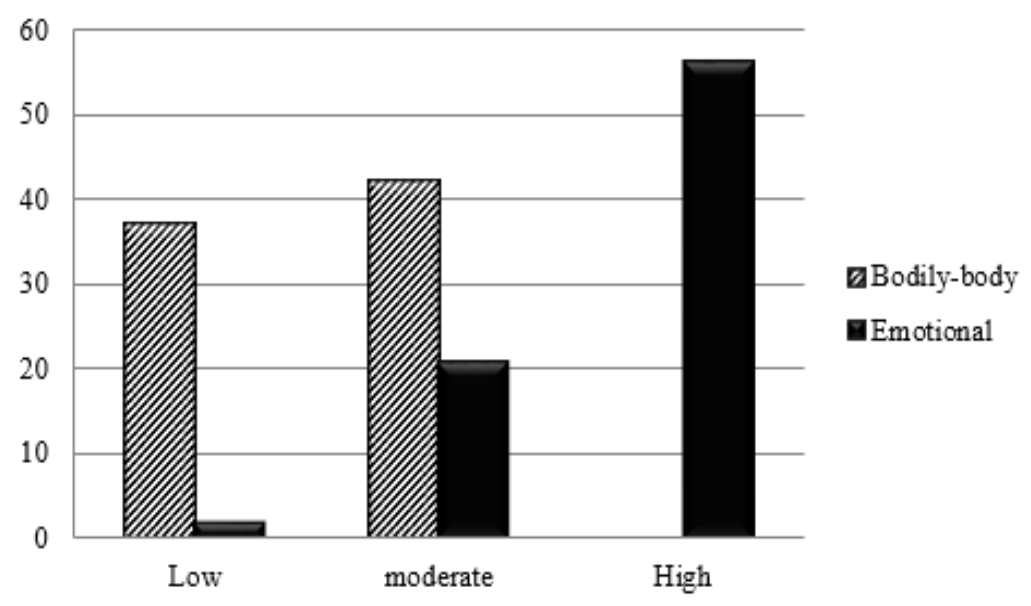

Figure 1. The Result of Evaluation 
lawful to make use of the capacity of young men and young women to kinesthetic the two ideas, an expression of the feelings of two whole years against two, and two to the physical dimension; It is what distinguishes the two specific agents, two dancers, and two athletes (Hasan, 2016). Cicero (2004) reported a more bodily than kinesthetic ability to temper all parts of the body, or lead the question to put a single product or emotional feelings. North Korea fist and interpret the two movements of nature, the shape of a man's body undergoes a complete configuration for the harmony between two minds. Like two men and two each of two or more happy brain games (1000 Tully 1000 Kernodle from 2004, Muftuler, 1000, two from 2009). At the end of the motor developer and professional ways to integrate the usability of the most diverse body expressive and directed to the edge (Alkayaly, 2013). In the absence of absolute radiation need to be improved on the physical scene kinesthetic character provides the curriculum and the tall body so that athletes reported two physical techniques kinesthetic talent in such a way that it is generally inelegant small muscle lecture function, balance, flexibility, mobility - thanks to physical movements is: muscle strength, sense of touch, and speed. Of love and understanding and the gestures and movements of love.

Gardner opposes the emphasis on markstructures and symbolic language in many colleges (Ekici, 2011). He argued that "different psychological approaches seem to be involved" in addressing the diversity of intelligent people (Gardner, 1995). Conditions for knowing songs may require the context of music, the use of musical symbols. The picture frames used in most MI schools and creative instruction related to many MI contexts are not necessarily the most commonly used and valuable resource of creative and imaginative children. the change in IM learning in elementary school has been analyzed by Mettetal, Jordan, \& Harper (1997). the monitoring method was used to resemble the information. From the point of view of their 3 subjects were updated: a) schoolchildren, parents, and educators were too condemned; (b) the teaching aids were improved and c) the variety of MI was required. The investigators placed particular emphasis on putting the new system into practice. Kornhaber (1999) has shown 3 ways in which learners have only one linguistic feasibility. the exams focused on the theory. the exams were composed of 8 fundamental elements. Kornhaber concluded that improving equity for subjacent learners is a quality device.

The model and academic achievements of university students who were tactile/kinesthetic and world-class. - assessing variance in the use of self-checklists, identifying gift items, for example 192 high school Chinese students from a multi-disciplinary perspectivell. Previously, it was determined that mental models of the same magnitude were almost perfect Lebanese and 252 Indian university students rated their skills on the basis of Gardner's many minds. Men identified a larger body than the (spiritual) body of the body at the same time as women went through mental and personal mental projections. Using the parent's professional measures, there is no absolute relationship to the brain's selfratings for each large sample from the United States of America previously reported.

The differences observed between the Indian and Lebanese samples on the objects of mental cognition, i.e. the verbal, spatial and logical routes, have technical methods, for expressive and directed tasks (Alkayaly, 2013). Not only does the lack of a Genius male body test point give us the need to improve the curriculum and two, we have found that athletes with large body mass have basic body knowledge such as coordination, good muscle performance, and physical fitness. Children with a kinesthetic bodily intelligence love the pastimeand movement.

Their community is their tool for learning, experience and explanation. Usually the trend is: Limited motorcycles: a natural course of how the body should function and react in a state of irritation, good body coordination, body control, balance, agility, grace, obedience, speed, exercise outdoors, dancing and sports, Excellent behavior with fingers and eye coordination, Performing movement in the prescribed manner, Using their body rather than different and skillful means for directed purposes, two Creating things with their hands, The enjoyment of a fun trip (Bailey, Armour, Kirk, Jess, Pickup, \& Sandford, 2009). The progress of new knowledge is to be more strong more than one spirit, shows a preference for educational reform. These theories can also choose to be used in creative dances in a way 
that emphasizes the importance of genius for the body - a movement in the university curriculum. Next case was some of the genres which gathered music unit can be assessed. Each brain explained his idea can be fully used and spread in leaning. Based on research conducted on young humans World School class, the first and most important dance encourages the spirit of the body - socialism, music, insults, atmosphere, genius and inner interactions arrive in $2 \mathrm{~d}$ (Keun \& Hunt, 2006).

Gardner (1983) maintains that: of the vast majority of the overall use of the human body, no one has reached a height greater than that of dance and that no one has succeeded in distinguishing the world. It turns out that the dances have good qualities linked to the examination of the capacities of the body. Academically, dances can provide a specific set of understanding and practice, affecting the mind of the body - that of bodybuilders, which players can hire (Blumenfeld, 2009). Brain - the defined body called capacity of a person used their body to fix specific difficulties, thoughts and ideas, and manipulative things. Based on the item, one of the characteristics of this case of talent is the competence to select psychologically in luxury to execute the skill to achieve its objectives. The $2 \mathrm{~d}$ characteristic of the genius of the body - is the improvement of talent in handling objects (Gardner, 1983). There seems to be a connection between the genius of the body and the desires and desires feelings of the leaning. The objectives of lesson were human movement presentations of willing the research (hoops, balls, scarves, magazines) during the current lesson, university learners are able to become more aware of their use and increase their ability to be deceived. Multiple assessments are used to better understand student readiness, while more effective teaching methods are used to improve student achievement.

School children get a brief overview while course tutorials need to be able to understand the different strengths coming from the learners, different topics need to be addressed. Each of these individual differences can have a profound impact on how high-level learners explore the subject and are important questions for instructors (Colquitt, Pritchard, Johnson, \& McCollum, 2017 ). This is largely based on the studies of researchers "obtaining consent for wellbeing and exclusive behavior. Learning has also suggested that primary school children from all over the world.

Human movement skills always need to be improved by the specialist of the main courses like kinetic, biomechanics, physiology, anatomy, nutrition in order to allow the good performance of the children. Teaching people is very linked to the specialization of the physical education and sport teacher (Sawyer \& Judge, 2012). Nevertheless many studies done with the research showed a particular interested on growing movement (Sikorska-Siudek, OlędzkaOręziak, \& Parzuchowska, 2006). The finding from leaning is linked on the children condition (Agarwal, 2012). In this research we found that there was a great problem about lesson students. In addition regular bodily endeavor is defined as "any bodily movement proved by way of the skeletal muscle these results in (Mansi \& Khaldi, 2015) energy expenditure".

\section{CONCLUSION}

The present study give guidelines on how we proceed physical education in primary school teaching. However, there are some obstacles block the educational quality for children, such as the lack of qualified teachers, teaching aids, training, equipment and sports facilities. These factors hinder the teaching of the discipline. These factors hinder the teaching of the discipline. To respond to these difficulties, the researchers advocate some solutions. Firstly, the education system should do its best to eliminate the obstacles. Secondly, the teaching quality at primary school must allow every child to have training about fundamental values, such as respect for the rules of social life and self-confidence. Regularly practice will contribute to the acquisition of physical, mental, intellectual, health as well as the acquisition of the essential motor skills for life.

\section{REFERENCES}

Agarwal, S. K. (2012). Cardiovascular benefits of exercise. International Journal of General Medicine, 5, 541-545. doi:10.2147/IJGM. S30113.

Alkayaly, G. (2013). Bodily-kinesthetic intelligence and its relation to selfconfidence and some basic football skills 
among young players under 16 years old. (Unpublished Master Research, Dialy University, Iraq).

Bailey, R. (2005). Evaluating the relationship between physical education, sport and social inclusion. Educational Review, 57(1), 71-90. doi:10.1080/001319104200 0274196 .

Bailey, R., Armour, K., Kirk, D., Jess, M., Pickup, I., \& Sandford, R. (2009). The educational benefits claimed for physical education and school sport: an academic review. Research Papers in Education, 24(1), 1-27. doi:10.1080/02671520701809817.

Barrington, E. (2004). Teaching to student diversity in higher education: How multiple intelligence theory can help. Teaching in Higher Education, 9(4), 421434. doi:10.1080/1356251042000252363

Blumenfeld, D. (2009). Bodily-kinesthetic intelligence and dance education: Critique, revision, and potentials for the democratic ideal. The Journal of Aesthetic Education, 43(1), 59-6. doi:10.1353/jae.0.0029.

Cicero, M. T. (2004). Letters to atticus (Vol. 5). Cambridge: Cambridge University Press.

Colquitt, G., Pritchard, T., Johnson, C., \& McCollum, S. (2017). Differentiating instruction in physical education: Personalization of learning. Journal of Physical Education, Recreation \& Dance, 88(7), 44-50. doi:10.1080/07303084.2017 .1340205 .

Ekici, S (2011). Multiple intelligence levels of physical education and sports school students. Educational Research and Reviews, 6(21), 1018-1026. doi:10.5897/ ERR11.176.

Ericsson, I. R. (2014). Effects of motor skills training and daily physical education: Research results in the Swedish Bunkeflo project. International Journal of Physical Education, 51(2), 19-29. http://www. schulsport.m-m-sports.com/wissenschaft/ front_content.php?idart=2569.
Ferguson-Patrick, K., Reynolds, R., \& Macqueen, S. (2018). Integrating curriculum: A case study of teaching global education. European Journal of Teacher Education, 41(2), 187-201. doi:10.1080/02619768.2 018.1426565 .

Gardner, H. (1983). Frames of mind. New York, NY: Basic Books.

Gardner, H. (1995). How are kids smart: Multiple intelligences in the classroom administrators' version. North Miami, FL: National Professional Resources.

Hasan, M. (2016). Bodily-kinesthetic intelligence and its relation to tactical thinking among advanced football layers. Journal of Sport Science, 9(2), 1-18.

Keun, L. L. \& Hunt, P. (2006). Creative dance: Singapore children's creative thinking and problem-solving responses. Research in Dance Education, 7(1), 35-65. doi:10.1080/14617890600610661.

Kornhabe, M. (1999). Multiple intelligences theory in practice. In J. H. Blocks, S.T. Everson, \& T. R. Guskey (Eds). Comprehensive school reform: A program perspective. Dubuque, IA: Kendall/Hunt, pp. 179-191.

Lynch, T. (2016). The future of health, wellbeing and physical education: Optimizing children's health through local and Global Community partnerships. Hampshire, Britania Raya: Palgrave Macmillan. doi:10.1007/978-3-319-31667-3.

Mansi, S., \& Khaldi, H. M. Al. (2015). Physical activity management and its role for health benefits: Narrative review. International Journal of Health Sciences (IJHS), 3(4), 95-107. doi:10.15640/ijhs.v3n4a9.

Mettetal, G. Jordan, C., \& Harper, S. (1997). Attitudes towards a multiple intelligences curriculum. Journal of Educational Research, 91(2), 115-122. doi:10.1080/00220679709597529.

Michelaki, E. \& Bournelli, P. (2016). The development of bodily - kinesthetic 
intelligence through creative dance for preschool students, Journal of Educational and Social Research, 6(3), 23-32. doi:10.5901/jesr.2016.v6n3p23.

Mitchell, M., \& Kernodle, M. (2004). Using multiple intelligences to teach tennis. Journal of Physical Education, Recreation \& Dance, 75(8), 27-32. doi:10.1080/0730 3084.2004.10607286.

Morgan, H. (1996). An analysis of Gardner's theory of multiple intelligence. Roeper Review, 18(4), 263-269. doi:10.1080/02783199609553756.

Muftuler, M. (2009). Specification of university students' free time preferences according to their multiple intelligence fields. Turkey Kick Box Federation Journal of Sport Science, 1(2).

Sawyer, T. H., \& Judge, L. W. (2012). The management of fitness, physical activity, recreation, and sport. Urbana, IL: Sagamore Publishing.

Schewe, M. L. (2002). Teaching foreign language literature: Tapping the students' bodilykinesthetic intelligence. In G. Brauer (Ed). Body and language: Intercultural learning through drama. London: Ablex Publishing, pp. 73-94.
Seitz, J. A. (1992). The development of bodilykinesthetic intelligence in children: Implications for education and artistry. Holistic Education Review, 5(2), 35-39

Sikorska-Siudek, K., Olędzka-Orȩziak, M., \& Parzuchowska, B. (2006). Coronary heart disease in women - Is there a gender problem? Family Medicine and Primary Care Review, 8(3), 1110-1115.

Siswantoyo, S., Shaari, J. S., \& Hooi, L. B., (2019). The effectiveness of psychological skills training program on netball shooting performance. Horizon Journal of Education, 38(1), 174-187. doi:10.21831/ cp.v38i1.23206.

Siswantoyo, S. (2014). Peningkatan power tungkai pesilat remaja melalui latihan pliometrik. [The improvement of the leg power of teenager fighters through plyometric training]. Cakrawala Pendidikan, 33(1), 80-91. doi:10.21831/ cp.vli1.1864.

Suherman, W. S., Dapan, D., Guntur, G., \& Muktiani, N. R. (2019). Development of traditional children play based instructional model to optimize development of kindergarteners' fundamental motor skill. Cakrawala Pendidikan, 39(2), 356-365. doi:10.21831/cp.v38i2.25289. 